\title{
Phage Selection of Peptide Macrocycles against $\beta$-Catenin To Interfere with Wnt Signaling
}

\author{
Davide Bertoldo, ${ }^{[\mathrm{a}]}$ Maola M. G. Khan, ${ }^{[\mathrm{a}]}$ Pierre Dessen, ${ }^{[\mathrm{c}]}$ Werner Held, ${ }^{[\mathrm{b}]}$ Joerg Huelsken, ${ }^{[\mathrm{c}]}$ and \\ Christian Heinis* ${ }^{*[a]}$
}

\begin{abstract}
Upregulation of $\beta$-catenin, the primary mediator of the Wnt signaling pathway, plays an important role in the tumorigenesis of several types of human cancer. Targeting $\beta$-catenin to interfere with its ability to serve as a translational co-activator is considered an attractive therapeutic approach. However, the development of inhibitors has been challenging because of the lack of obvious binding pockets for ligands, and because inhibitors should not interfere with other $\beta$-catenin functions. Only two ligands with known molecular interactions with $\beta$ catenin have been developed so far, and are based on stabilized $\alpha$-helical peptides. In this study, we screened a large combinatorial library of bicyclic peptides by phage display. Binders to different surface regions of $\beta$-catenin were identified. The binding site of one group of ligands was mapped to the interaction region of the translational Wnt inhibitor ICAT (inhibitor of $\beta$-catenin and Tcf), which is a prime target site on $\beta$-catenin for therapeutic intervention, and to which no ligands could be developed before.
\end{abstract}

$\beta$-Catenin is a multifunctional protein that plays important roles in cell-cell adhesion at adherens junctions and in the Wnt growth factor signaling pathway ${ }^{[1]}$ In its latter role, $\beta$-catenin regulates many biological processes, including embryogenesis, development, and adult tissue homeostasis. Deregulation of the Wnt pathway is associated with multiple diseases, including various types of cancer. ${ }^{[2]}$ In the absence of a Wnt signal, $\beta$-catenin turnover is regulated by a multicomponent complex in the cytoplasm called the $\beta$-catenin destruction complex, which catalyzes the phosphorylation of $\beta$-catenin and thus labels it for ubiquitin-dependent degradation by the proteasome. $^{[3]}$ In the presence of a Wnt signal, the phosphorylation of $\beta$-catenin is inhibited, which leads to its accumulation in the cytosol. Accumulated $\beta$-catenin translocates to the nu-

[a] D. Bertoldo, Dr. M. M. G. Khan, Prof. C. Heinis

Institute of Chemical Sciences and Engineering

Ecole Polytechnique Fédérale de Lausanne (EPFL)

1015 Lausanne (Switzerland)

E-mail:christian.heinis@epfl.ch

[b] Prof. W. Held

Swiss Institute for Experimental Cancer Research (ISREC)

Ecole Polytechnique Fédérale de Lausanne (EPFL)

1015 Lausanne (Switzerland)

[c] P. Dessen, Prof. J. Huelsken

Ludwig Center for Cancer Research, Department of Oncology

University of Lausanne, 1066 Epalinges (Switzerland)

$\square$ Supporting information for this article is available on the WWW under http://dx.doi.org/10.1002/cmdc.201500557. cleus, where it interacts with numerous partners including proteins of the Tcf/LEF family, and together they activate the transcription of Wnt-responsive genes. ${ }^{[3]}$ Structurally, $\beta$-catenin contains a series of 12 armadillo repeats, each of which is approximately 40 amino acids long, flanked by unstructured $\mathrm{N}$ - and $\mathrm{C}-$ terminal domains. ${ }^{[4]}$ Around 40 different $\beta$-catenin interaction partners have been described. ${ }^{[1,4]}$

Abnormal activation of the $W n t / \beta$-catenin pathway is caused mostly by loss-of-function mutations in the tumor suppressors adenomatous polyposis coli protein (APC) and axin, or gain-offunction mutations in $\beta$-catenin, causing over-proliferation of the cell and the onset of tumorigenesis owing to a constitutive increase in the levels of nuclear $\beta$-catenin. ${ }^{[2]}$ Mutations in proteins of the Wnt pathway are believed to be present in around $20 \%$ of all human cancers, with the majority of colorectal cancers bearing a mutation in the Wnt signaling pathway. ${ }^{[5]}$ One of the most frequent mutations is found in the APC gene, causing the inherited conditional familial adenomatous polyposis (FAP), which results from the loss of one allele of $A P C$, leading to the formation of a high number of intestinal polyps and an increased predisposition to colorectal cancer. ${ }^{[5]}$

Owing to the strong dependence of many tumors on Wnt signaling for growth and survival, inhibition of this pathway is considered an attractive therapeutic approach. Several strategies toward the inhibition of canonical Wnt signaling have been reported in recent years. ${ }^{[6,7]}$ Compounds were identified that either inhibit components upstream of the destruction complex, activate the destruction complex to decrease $\beta$-catenin levels, or inhibit the transcriptional activator complex. Targeting $\beta$-catenin to interfere with its ability to serve as a translational co-activator is considered a particularly compelling approach because the transcriptional complex is the final effector of canonical Wnt signaling, and because it is downstream of most cancer-associated Wnt pathway mutations. A challenge with $\beta$-catenin as a target is that it also plays critical roles in other functions such as in cadherin binding, thus being important for cell-cell adhesion at adherens junctions. ${ }^{[8]}$ Several $\beta$ catenin binding partners that serve in different roles have overlapping binding sites, making it a significant challenge to interfere with Wnt signaling exclusively. ${ }^{[1,7,9]}$ For example, a compound that disrupts the $\beta$-catenin-Tcf interaction could also interfere with the $\beta$-catenin-cadherin and $\beta$-catenin-APC interactions, as Tcf, cadherin, and APC share the core binding site in the groove formed by the armadillo repeat domain. Another challenge in targeting $\beta$-catenin is its rather flat and featureless surface, which makes the development of small-molecule binders difficult. ${ }^{[9]}$ 
Screening of small-molecule libraries led to the identification of several inhibitors of the transcriptional activator complex. ${ }^{[7]}$ However, the reported small-molecule inhibitors have low affinities and/or their exact molecular mechanisms have not been identified. Inhibitors with defined binding mechanisms were designed based on the $\alpha$-helices of $\beta$-catenin interaction partners. One such peptide developed was a hydrocarbon-stapled $\alpha$-helical peptide derived from B-cell lymphoma 9 (BCL9), a co-activator for $\beta$-catenin-mediated transcription. ${ }^{[10]}$ The peptide was shown to dissociate native $\beta$-catenin-BCL9 complexes and to suppress Wnt transcription. Another stapled peptide $\beta$ catenin antagonist was developed based on an $\alpha$-helical peptide from axin binding to a surface region within the $\beta$-catenin-Tcf binding interface. ${ }^{[11]}$ The peptide, named fStAx-34, binds $\beta$-catenin with a $K_{d}$ value of $8 \mathrm{~nm}$ and selectively suppresses mRNA levels of canonical Wnt-driven genes. The development of stapled peptide ligands to more surface regions of $\beta$-catenin is limited by the requirement for structural information of $\beta$-catenin binding partners that bind via $\alpha$-helices and the availability of proteins binding via $\alpha$-helices.

In this work, we raised the question if ligands to a wider range of $\beta$-catenin surface regions could be developed by screening combinatorial libraries of random cyclic peptides using phage display. We reasoned that such ligands could be instrumental in the search for regions on the surface of $\beta$-catenin that can be targeted for blocking transcriptional activation of Wnt genes without interfering with the destruction pathway or other important functions of $\beta$-catenin such as cell-cell adhesion. We further reasoned that peptidic ligands that fulfill the latter requirements could be used as templates to engineer cell-permeable macrocycles for therapeutic application. A peptide format that is suited for high-affinity binding is that of bicyclic peptides. High-affinity ligands based on bicyclic peptides were recently developed for a range of various protein targets using a strategy based on phage display. ${ }^{[12]}$ In this method, peptides are displayed on phage and chemically cyclized by reacting three cysteines, two flanking the peptide and one being in the middle, with reagents containing three thiol-reactive groups. Binders are subsequently isolated in iterative rounds of affinity selection as in conventional phage-panning procedures. Bicyclic peptide phage display typically yields binders to several different surface regions of a protein target, and the binding affinities tend to be in the low-micromolar to picomolar range. ${ }^{[12-15]}$

We prepared phage displaying $>4 \times 10^{9}$ different peptides of the format $\mathrm{ACX}_{6} \mathrm{CX}_{6} \mathrm{CG}^{[12]}$ and cyclized the peptides in separate reactions with the three chemical linkers: 1,3,5-tris(bromomethyl)benzene (TBMB), 1,3,5-triacryloyl-1,3,5-triazinane (TATA), and $\quad N, N^{\prime}, N^{\prime \prime}$-(benzene-1,3,5-triyl)-tris(2-bromoacetamide) $(\mathrm{TBAB}){ }^{[16]}$ to obtain three libraries with a total diversity exceeding 12 billion peptide macrocycles. $\beta$-Catenin containing the 12 armadillo repeats but not the flexible $\mathrm{N}$ terminus (residues 129-781; Supporting Information Figure S1) was biotinylated at amino groups and immobilized on streptavidin- or neutravidin-coated magnetic beads. A careful choice of buffers was required to prevent aggregation of $\beta$-catenin during the procedures of $\beta$-catenin purification, biotinylation, removal of un- reacted biotin, and immobilization, to eventually present the target protein on the solid support in its native conformation. The three libraries were panned in parallel against $\beta$-catenin. Streptavidin (rounds 1 and 3) and neutravidin beads (round 2) were used alternatingly to prevent enrichment of binders to these proteins. ${ }^{[17]}$ The number of phage captured in the affinity selections increased significantly in the second and third rounds of panning. In the third round, the number of phage isolated from the three libraries was several orders of magnitude higher than in control reactions in which $\beta$-catenin was omitted, indicating that target-specific binders were isolated (Supporting Information Table 1).

Around 170000, 69000, and 84000 clones isolated from the libraries of peptides cyclized with TBMB, TATA, and TBAB were sequenced, respectively. Alignment of the most abundant peptide sequences of each selection by using previously developed software ${ }^{[18]}$ revealed many different consensus sequences (Figure 1). For peptides cyclized with TBMB, TATA, and TBAB, 12,5 , and 4 different consensus sequences were found. The number of identified consensus sequences was comparatively high: in most cases bicyclic peptide phage selections against other targets yielded no more than a few different consensus sequences. ${ }^{[12-16]}$ Peptides sharing a consensus sequence likely form the same molecular interactions with the target and thus bind to the same surface region. Conversely, peptides of different consensus groups form different molecular contacts. Having identified numerous consensus motifs, it was likely that ligands to several different surface regions were isolated. This identification of many binding sites can be explained by the fact that $\beta$-catenin has many natural protein binding partners and thus suitable binding faces. Comparison of the consensus sequences with known $\beta$-catenin peptide binding motifs identified one striking similarity: the consensus motif " $\mathrm{L} / \mathrm{vLD}$ " found in TBAB-cyclized peptides (first consensus group in Figure 1, right column) is similar to the tetrapeptide "SILD" of the axin $\alpha$-helix (EENPESILDEHVQRVMK) that forms direct contacts with $\beta$-catenin. ${ }^{[19]}$ The similarity suggested that peptides of this consensus group bind to the armadillo repeats 3 and 4 through similar interactions as the $\alpha$-helix of axin.

Representative peptides of the different consensus groups were chemically synthesized. Fluorescein was linked to their $\mathrm{N}$ termini to allow measurement of binding to $\beta$-catenin by fluorescence polarization. Among the 22 peptides that were tested, four were observed to bind with single-digit micromolar $K_{\mathrm{d}}$ values, and two showed $K_{\mathrm{d}}$ values between 20 and $30 \mu \mathrm{M}$ (Figure 1). The remaining peptides showed no or only weak binding to $\beta$-catenin at the highest concentration tested $(8.5 \mu \mathrm{M})$. The six bicyclic peptides binding $\beta$-catenin with micromolar $K_{d}$ values were isolated from the peptide libraries cyclized with TBMB (BC1, 2nd consensus group; $B C 2$, 5th consensus group), TATA (BC3, 1st consensus group), and TBAB (BC4, $B C 5$, and $B C 6,2$ nd consensus group).

To identify the binding sites of the bicyclic peptides, competition binding experiments were performed using the two natural $\beta$-catenin interaction partners axin and ICAT. Axin binds via an $\alpha$-helix to armadillo repeats 3 and 4 of $\beta$-catenin $\left(K_{d}=\right.$ $8.4 \mathrm{~nm})$. The binding site overlaps with the one of the C-termi- 

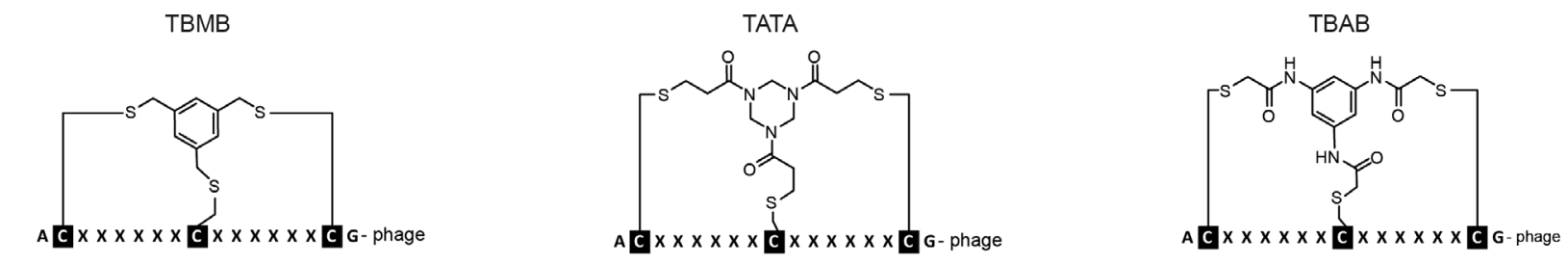

\begin{tabular}{|c|c|c|c|}
\hline Peptide & Sange & r NGS & $\kappa_{d}(\mu \mathrm{M})$ \\
\hline 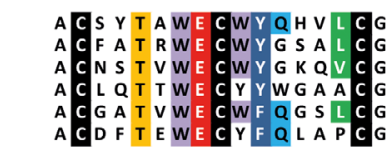 & $\begin{array}{ll}\mathbf{G} & \\
\mathbf{G} & \\
\mathbf{G} & 1 \\
\mathbf{G} & 1 \\
\mathbf{G} & \\
\mathbf{G} & \end{array}$ & $\begin{array}{r}160 \\
5 \\
5 \\
409 \\
21 \\
6\end{array}$ & \\
\hline 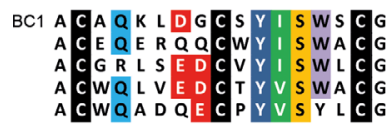 & $\begin{array}{ll}G & 1 \\
G & \\
G & \\
G & \\
G & \end{array}$ & $\begin{array}{r}386 \\
350 \\
8 \\
94 \\
2913\end{array}$ & $4.57 \pm 0.57$ \\
\hline 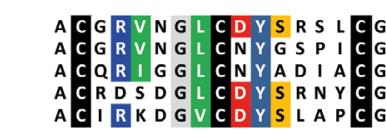 & $\begin{array}{ll}\mathbf{G} & \\
\mathbf{G} & \\
\mathbf{G} & \\
\mathbf{G} & \\
\mathbf{G} & 1\end{array}$ & $\begin{array}{r}18 \\
8 \\
20 \\
19 \\
79\end{array}$ & \\
\hline 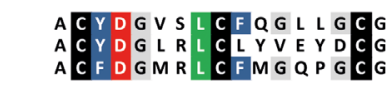 & $\begin{array}{ll}G & 1 \\
G & \\
G & \end{array}$ & $\begin{array}{r}659 \\
7 \\
43\end{array}$ & $\gg>10$ \\
\hline 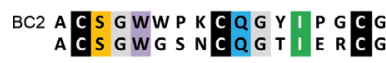 & G 25 & $\begin{array}{r}108591 \\
17\end{array}$ & $3.82 \pm 0.17$ \\
\hline 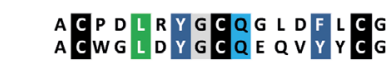 & & $\begin{array}{r}137 \\
17\end{array}$ & \\
\hline 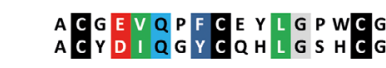 & & $\begin{array}{l}521 \\
356\end{array}$ & \\
\hline 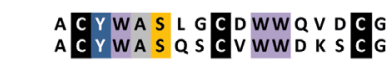 & $\begin{array}{ll}G & 1 \\
G & \end{array}$ & $\begin{array}{r}747 \\
35\end{array}$ & $\gg 10$ \\
\hline 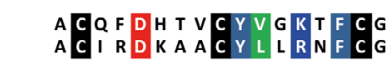 & & $\begin{array}{r}374 \\
10\end{array}$ & $\gg>10$ \\
\hline 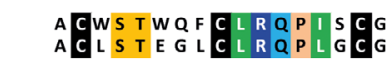 & $\begin{array}{ll}\mathbf{G} & 1 \\
\mathbf{G} & \end{array}$ & $\begin{array}{r}756 \\
9\end{array}$ & $>>10$ \\
\hline 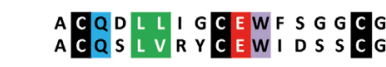 & $\begin{array}{ll}\mathbf{G} & 1 \\
\mathbf{G} & \end{array}$ & $\begin{array}{l}60 \\
33\end{array}$ & \\
\hline 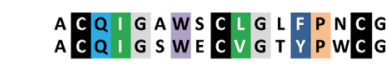 & $\begin{array}{ll}G & 5 \\
G & \end{array}$ & $\begin{array}{r}1934 \\
24\end{array}$ & \\
\hline 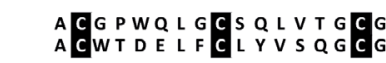 & $\mid \begin{array}{lr}G & 27 \\
G & 3\end{array}$ & $\begin{array}{r}36109 \\
2433\end{array}$ & $\gg 10$ \\
\hline
\end{tabular}

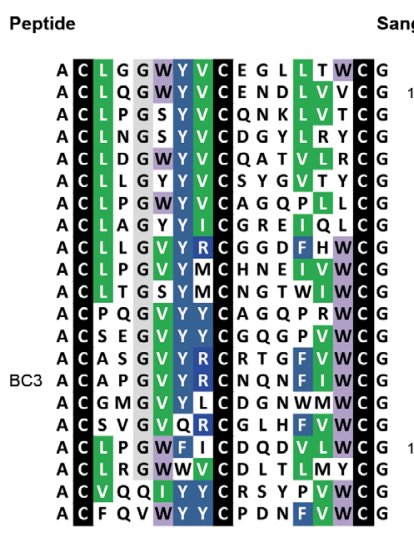

Sanger NGS $K_{d}(\mu \mathrm{M})$
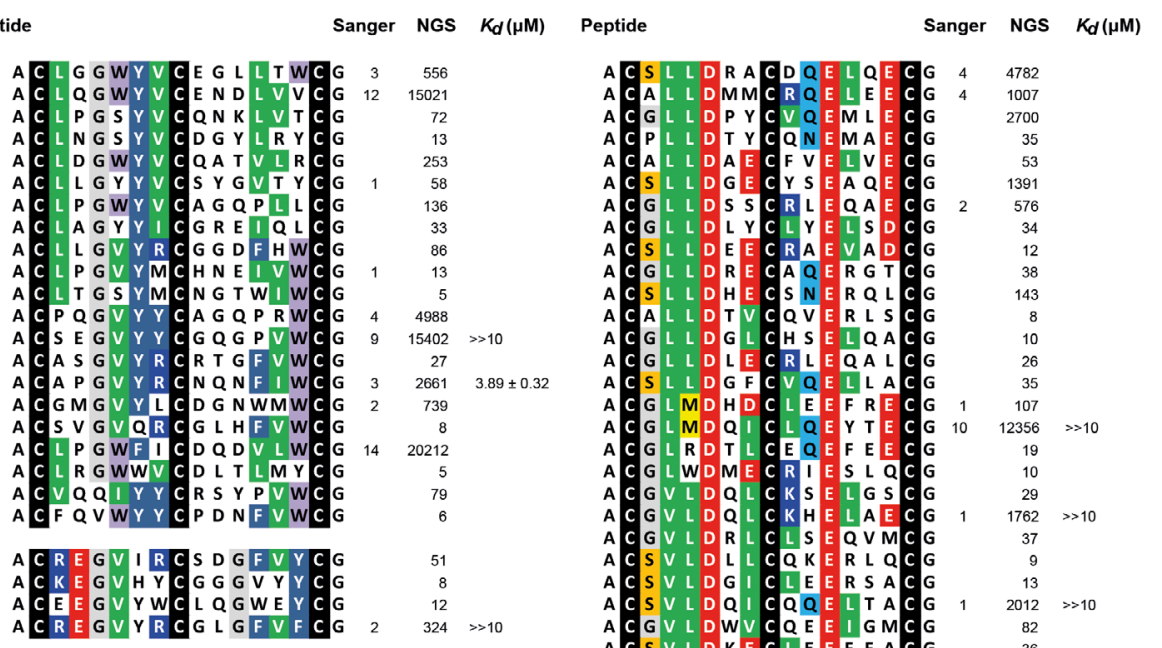

$\begin{array}{rl}556 & \\ 15021 & \\ 72 & \\ 13 & \\ 253 & \\ 58 & \\ 136 & \\ 33 & \\ 86 & \\ 13 & \\ 5 & \\ 4988 & \\ 15402 & >10 \\ 27 & \\ 2661 & 3.89 \pm 0.32 \\ 739 & \\ 8 & \\ 20212 & \\ 5 & \\ 79 & \\ 6 & \\ & \\ 51 & \\ 8 & \\ 12 & \\ 324 & >10 \\ & \\ 530 & \\ 11 & \\ 7 & \\ 42 & \\ & \\ 606 & \\ 46 & \\ 33 & \\ 357 & \\ 135 & \\ 3855 & >>10 \\ \end{array}$
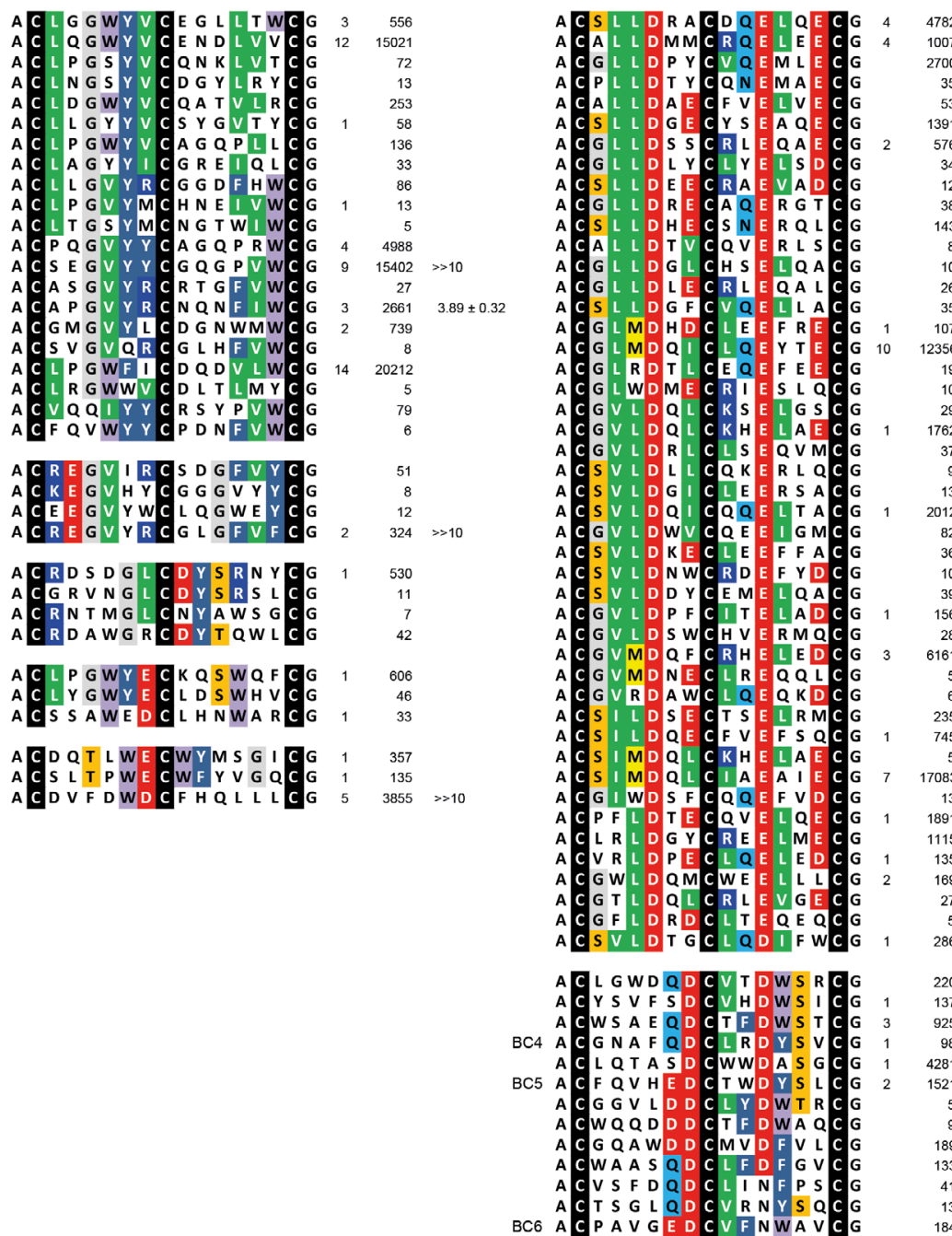

$A$ A S L T P W E C WF Y V G Q C G
A C D V F D WD C F H Q L L L C G

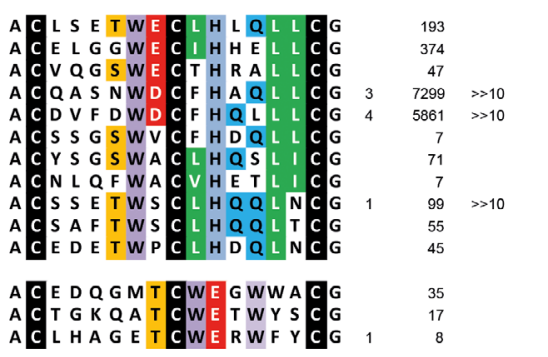

Figure 1. Sequences of phage-selected bicyclic peptides. Peptides of the $6 \times 6$ phage display library were cyclized with TBMB, TATA, and TBAB to obtain the indicated bicyclic peptide format. " $X$ " indicates any of the 20 natural amino acids. Peptides sharing similar sequences are aligned in groups, and amino acid similarities are highlighted in color. The abundance of the peptide identified by Sanger sequencing and ion torrent next-generation sequencing (NGS) is indicated. $K_{d}$ values were determined for peptides labeled with fluorescein at the $\mathrm{N}$ terminus. Standard deviations are indicated.

nal $\alpha$-helices of Tcf that docks in the groove of armadillo repeats 3 and 4 (Figure 2, surface in red). ${ }^{[19]}$ A synthetic peptide with the sequence of the $\alpha$-helix was previously found to bind $\beta$-catenin, and its binding affinity could be enhanced by 'sta- 

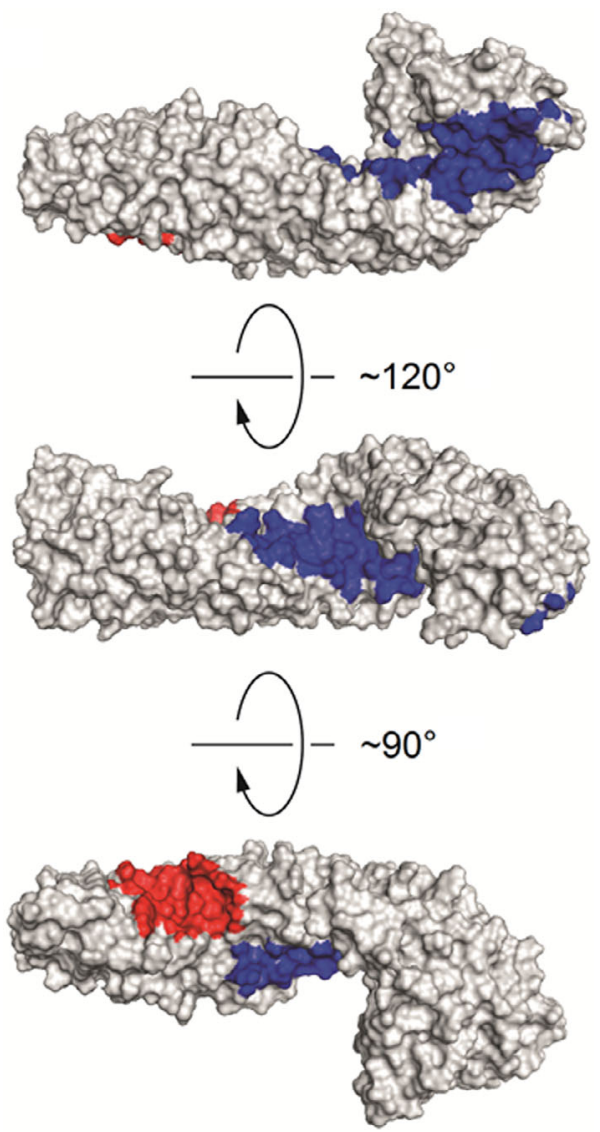

Figure 2. Surface of the $\beta$-catenin structure. The binding interfaces between $\beta$-catenin and the axin $\alpha$-helix (red), and between $\beta$-catenin and ICAT (blue) are indicated.

pling' the helix with a hydrocarbon linker. ${ }^{[11]}$ We thus used such a stabilized helical peptide for the competition binding experiment $\left(K_{\mathrm{d}}=8.4 \mathrm{~nm}\right)$. ICAT is a translational Wnt inhibitor. The 81 amino acid protein binds with its $\mathrm{N}$-terminal helical domain to armadillo repeats 11 and 12 of $\beta$-catenin, and with its $\mathrm{C}$-terminal-extended region to the groove formed by armadillo repeats $5-10$ of $\beta$-catenin $\left(K_{d}=3.1 \mathrm{~nm}\right.$; Figure 2 , surface in blue). ${ }^{[20]}$ For the competition binding experiment, $\beta$-catenin at various concentrations $(150 \mathrm{~nm}-19.2 \mu \mathrm{M})$ was incubated with excess axin $\alpha$-helix $(25 \mu \mathrm{M})$ or ICAT $(25 \mu \mathrm{M})$. The complexed proteins were added to fluorescence-labeled bicyclic peptides $(100 \mathrm{~nm})$, and the fraction of bound peptide was quantified by measuring fluorescence polarization (Figure 3). The axin $\alpha$-helix did not block the interaction of any of the bicyclic peptides with $\beta$-catenin. The binding of peptides $B C 4, B C 5$, and $B C 6$ was slightly weakened, possibly through conformational changes in $\beta$-catenin imposed by the axin helix or through unspecific interactions of the axin peptide that was added at high concentration. Conversely, ICAT competed strongly with the binding of the bicyclic peptides BC1, BC4, BC5, and BC6. Even at the highest concentration of $\beta$-catenin, no increase in fluorescence polarization was observed for the four peptides, indicating that ICAT fully blocks their binding. Peptides BC4, BC5, and $B C 6$ share the same consensus sequence, suggesting that they bind to the same epitope. Peptide $\mathrm{BC} 1$ belongs to a different
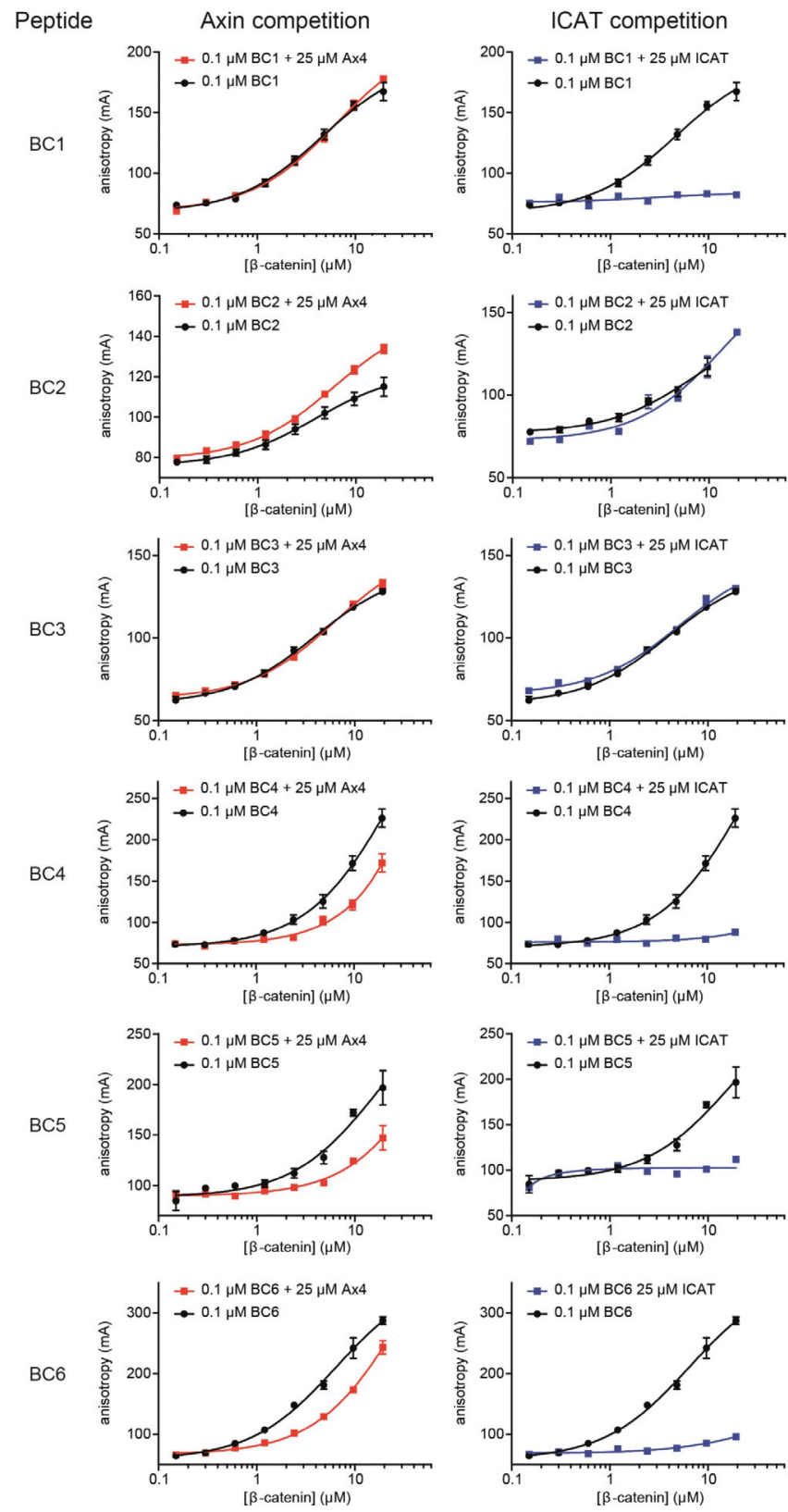

Figure 3. Competition of bicyclic peptides and natural protein ligands for binding to $\beta$-catenin. Bicyclic peptides labeled with fluorescein $(0.1 \mu \mathrm{m})$ were incubated with increasing concentrations of $\beta$-catenin, and the extent of binding was quantified by fluorescence polarization (black curves). The binding assay was repeated in presence of axin $\alpha$-helix ( $25 \mu \mathrm{M}$, red curves) or ICAT ( $25 \mu \mathrm{M}$, blue curves). Average values and standard deviations of three measurements are shown.

consensus group, indicating that it binds $\beta$-catenin differently than the other three peptides.

ICAT binds to an extended surface region of $\beta$-catenin, and many binding sites can be envisioned for the four bicyclic peptides. Structural analysis of $\beta$-catenin with bound peptide will be required to identify the exact binding sites of the bicyclic peptides. The finding that the bicyclic peptides bind to the same surface region as ICAT was exciting, as ICAT is a native inhibitor of the Tcf- $\beta$-catenin interaction that decreases tran- 
scription activation. There is a chance that peptide macrocycles binding to the same epitope will inhibit $\beta$-catenin-mediated transcription too. Given the moderate binding affinities of the bicyclic peptides in the micromolar range, an affinity maturation will be required before the peptides can be tested in cells for their ability to block $\beta$-catenin-mediated signaling. Additionally, the peptides might need to be modified to facilitate their transport into cells, either by conjugating them to a cellpenetrating peptide, or by substituting the charged residues and eliminating several polar groups.

In summary, a range of $\beta$-catenin ligands could be isolated from bicyclic peptide phage display libraries. The large number of consensus sequences identified indicates that the peptide macrocycles interact with $\beta$-catenin via diverse peptide binding motifs, and bind potentially to various regions of the target protein. Competition experiments with native $\beta$-catenin binding partners indeed identified multiple binding sites. Several peptides interfered with ICAT and thus bound to a prime target site on $\beta$-catenin for therapeutic intervention. While more work is required to locate the exact binding sites, to affinity-mature the binders, and to assess their activity in cells and in vivo, the results revealed that $\beta$-catenin offers a wide range of binding sites for peptide macrocycles, and encourages the screening of larger cyclic peptide diversities to identify even more diverse binders. If binders that block Wnt signaling without interfering with essential activities of $\beta$-catenin can be identified, they might be converted into cyclic peptidomimetics for developing anticancer therapeutics.

\section{Experimental Section}

$\boldsymbol{\beta}$-Catenin expression and purification: Human $\beta$-catenin (residues 129-781) was expressed in E. coli as a fusion protein containing at the $\mathrm{N}$ terminus a streptavidin binding peptide, a $\mathrm{His}_{6}$ tag, and a TEV cleavage site (the sequence is provided in the Supporting Information). The expression vector was transformed into Rosetta blue E. coli electro-competent cells, and cells of a single colony were grown in $500 \mathrm{~mL}$ TBG media $(1.2 \% \mathrm{w} / \mathrm{v}$ tryptone, $2.4 \% \mathrm{w} / \mathrm{v}$ yeast extract, $0.4 \% v / v$ glycerol, $17 \mathrm{mM} \mathrm{KH}_{2} \mathrm{PO}_{4}, 72 \mathrm{mM} \mathrm{K}_{2} \mathrm{HPO}_{4}$ ) supplemented with kanamycin $\left(50 \mu \mathrm{g} \mathrm{mL}^{-1}\right)$ and chloramphenicol $\left(30 \mu \mathrm{g} \mathrm{m}^{-1}\right)$ at $37^{\circ} \mathrm{C}$ to an $\mathrm{OD}_{600}$ of 0.8 . The culture was then cooled to $21{ }^{\circ} \mathrm{C}$, and protein production was induced with $0.1 \mathrm{~mm}$ isopropyl $\beta$-D-1-thiogalactopyranoside (IPTG) for $16 \mathrm{~h}$. The bacteria were pelleted by centrifugation $\left(15 \mathrm{~min}, 4^{\circ} \mathrm{C}, 5000 \mathrm{~g}\right)$ and resuspended in $25 \mathrm{~mL}$ ice-cold buffer A ( $50 \mathrm{mM}$ Tris. $\mathrm{HCl}, \mathrm{pH} 8.5,15 \mathrm{~mm}$ imidazole, $10 \% \mathrm{v} / \mathrm{v}$ glycerol). Bacteria were lysed by sonication ( 5 cycles of $90 \mathrm{~s}$ sonication and $90 \mathrm{~s}$ cooling) on ice, and bacterial debris pelleted by centrifugation at $4{ }^{\circ} \mathrm{C}$ for $30 \mathrm{~min}$ at $4000 \mathrm{rpm}$ $(2700 \mathrm{~g})$. The supernatant was run through a His Trap FF $1 \mathrm{~mL}$ column (GE Healthcare Bio-Sciences $A B$ ), washed with $15 \mathrm{~mL}$ buffer $A$, and eluted via a linear gradient $(0-100 \%)$ of buffer $B(50 \mathrm{~mm}$ Tris. $\mathrm{HCl}, \mathrm{pH} 8.5,150 \mathrm{~mm}$ imidazole, $10 \% \mathrm{v} / \mathrm{v}$ glycerol) in $30 \mathrm{~mL}$. The buffer of the eluted protein was exchanged to buffer $C(50 \mathrm{~mm}$ Tris, pH 8.8, $10 \mathrm{~mm} \mathrm{NaCl}, 10 \% \mathrm{v} / \mathrm{v}$ glycerol). Protein purity was assessed by SDS-PAGE analysis. Aliquots of the protein were stored at $-80^{\circ} \mathrm{C}$.

$\boldsymbol{\beta}$-Catenin biotinylation: For phage selections, the $\mathrm{N}$-terminal streptavidin binding peptide tag of the $\beta$-catenin fusion protein was removed with TEV protease as follows: After $\mathrm{His}_{6}$-tag purifica- tion, $\beta$-catenin was dialyzed overnight at $4^{\circ} \mathrm{C}$ in elution buffer ( $30 \mathrm{mM}$ imidazole, $10 \% \mathrm{v} / \mathrm{v}$ glycerol, $\mathrm{pH}$ 8.3) in the presence of TEV protease at a ratio of 1:20 $\mathrm{w} / \mathrm{W}$ TEV protease/ $\beta$-catenin. The TEV protease carrying a $\mathrm{His}_{6}$ tag was removed by incubating the mixture for $1 \mathrm{~h}$ at $4^{\circ} \mathrm{C}$ with Ni-NTA slurry. The Ni-NTA slurry was pelleted by centrifugation $\left(2 \mathrm{~min}, 4^{\circ} \mathrm{C}, 700 \mathrm{~g}\right.$ ), and the supernatant containing $\beta$-catenin was recovered. The buffer of the protein was changed to PBS $\left(137 \mathrm{~mm} \mathrm{NaCl}, 2.7 \mathrm{mM} \mathrm{KCl}, 100 \mathrm{mM} \mathrm{Na}_{2} \mathrm{HPO}_{4}\right.$, $2 \mathrm{mM} \mathrm{KH}_{2} \mathrm{PO}_{4}, \mathrm{pH} 7.4$ ) using a PD-10 desalting column (GE Healthcare Bio-Sciences $A B)$. The protein $(1 \mu \mathrm{M})$ was biotinylated using a 50 -fold molar excess $(50 \mu \mathrm{M})$ of Sulfo-NHS-LC-Biotin (Thermo Fisher Scientific) for $60 \mathrm{~min}$ at room temperature. Unreacted SulfoNHS-LC-Biotin was removed by gel filtration using a PD-10 desalting column and TNC buffer $(50 \mathrm{~mm}$ Tris, $\mathrm{pH} 8.8,150 \mathrm{~mm} \mathrm{NaCl}$, $10 \mathrm{mM} \mathrm{CaCl}_{2}, 0.02 \% \mathrm{NaN}_{3}, 0.05 \%$ Brij 35). The efficiency of the biotinylation reaction was assessed by capturing the protein on $20 \mu \mathrm{L}$ streptavidin beads (Dynabeads M-280 Streptavidin, Invitrogen Dynal Biotech AS) and analysis of bound protein by SDS-PAGE.

Phage display selection: Phage of the $6 \times 6$ peptide library ${ }^{[12]}$ were produced and purified on a $1.5 \mathrm{~L}$ scale. Peptides displayed on the phage were reduced with TCEP, and the reducing agent was removed as previously described. ${ }^{[17]}$ The phage were split into three tubes to cyclize the peptides with TBMB $(20 \mu \mathrm{M})$, TATA $(150 \mu \mathrm{M})$, and TBAB $(40 \mu \mathrm{M})$ as described previously. ${ }^{[16]}$ Each of the three bicyclic peptide phage libraries was subjected to affinity selections as described previously. ${ }^{[17]}$ For each selection, $5 \mu \mathrm{g}$ biotinylated human $\beta$-catenin immobilized on $50 \mu \mathrm{L}$ magnetic streptavidin (1st and 3 rd round) or neutravidin beads ( 2 nd round) was used. Neutravidin-coated magnetic beads were used in the second round of selection to prevent enrichment of streptavidin-specific peptides. Eluted phage were incubated with $30 \mathrm{~mL}$ of exponentially growing TG1 E. coli cells $\left(\mathrm{OD}_{600}=0.4\right)$ for $90 \mathrm{~min}$. Bacteria were plated on large $2 \mathrm{YT} / \mathrm{chloramphenicol}$ plates $\left(30 \mu \mathrm{g} \mathrm{m}^{-1}\right)$ and incubated at $37^{\circ} \mathrm{C}$. The cells were harvested the next day with $2 \mathrm{YT}$ media and stored in $15 \%$ glycerol at $-80^{\circ} \mathrm{C}$.

Phage DNA sequencing: For Sanger sequencing, cells of single colonies were grown in $5 \mathrm{~mL}$ LB media containing chloramphenicol $\left(30 \mu \mathrm{g} \mathrm{mL}^{-1}\right)$, DNA isolated and sequenced (Macrogen). For highthroughput sequencing, cells of colonies were pooled and DNA isolated. The DNA was processed as described previously ${ }^{[18]}$ and sequenced by ion torrent sequencing. The data were analyzed using software described previously. ${ }^{[18]}$

Peptide synthesis: Peptides were synthesized on an Advanced ChemTech $348 \Omega$ peptide synthesizer (AAPPTec) by standard Fmoc solid-phase chemistry using Rink Amide AM resin $(0.03 \mathrm{mmol}$ scale; GL Biochem) and DMF as solvent. Each amino acid (4 equiv) was coupled twice (RT, $30 \mathrm{~min}, 400 \mathrm{rpm}$ ) using HBTU/HOBt (4 equiv each) and DIPEA (6 equiv). The resin was washed four times with DMF after the coupling reaction. Fmoc groups were removed twice using $20 \%(\mathrm{v} / \mathrm{v})$ piperidine in DMF (RT, $5 \mathrm{~min}, 400 \mathrm{rpm}$ ). The resin was washed five times with DMF after deprotection.

$\mathrm{N}$-Terminal labeling of the peptides with 5(6)-carboxyfluorescein: 5(6)-carboxyfluorescein (Acros Organics) was coupled to the $\mathrm{N}$ terminus of peptides before cleavage from the Rink Amide resin. 5(6)-Carboxyfluorescein $(0.06 \mathrm{mmol}, 2$ equiv), DCC $(0.06 \mathrm{mmol}$, 2 equiv), and $\mathrm{HOBt}(0.12 \mathrm{mmol}, 4$ equiv) were each dissolved in $0.5 \mathrm{~mL}$ DMF. The chemicals were added to $\mathrm{N}$-terminal-deprotected peptide $(0.03 \mathrm{mmol})$ and mixed at RT for $1 \mathrm{~h}$ at $400 \mathrm{rpm}$. The resin was washed four times with DMF. 
Peptide cleavage from the resin: Peptides were deprotected and cleaved from the Rink Amide AM resin by incubation with $5 \mathrm{~mL}$ cleavage solution $(90 \% v / v$ TFA, $2.5 \% v / v$ 1,2-ethanedithiol, $2.5 \%$ $w / v$ phenol, $2.5 \% v / v$ thioanisole, $2.5 \% v / v \mathrm{H}_{2} \mathrm{O}$ ) for $2 \mathrm{~h}$ with shaking. The resin was removed by filtration under vacuum, and the peptides were precipitated with ice-cold $\mathrm{Et}_{2} \mathrm{O}(50 \mathrm{~mL})$, incubated for $30 \mathrm{~min}$ at $-20^{\circ} \mathrm{C}$, and pelleted by centrifuging for $5 \mathrm{~min}$ at $4000 \mathrm{rpm}(2700 \mathrm{~g})$. The $\mathrm{Et}_{2} \mathrm{O}$ was discarded, and the process was repeated twice using 30 and $20 \mathrm{mLEt} \mathrm{E}_{2} \mathrm{O}$, respectively. The remaining solvent was evaporated at RT.

Peptide cyclization with chemical linkers: The crude peptide (typically $\sim 40 \mathrm{mg}$ ) was dissolved in $4.5 \mathrm{~mL} 50 \% \mathrm{MeCN}$ and $50 \% \mathrm{H}_{2} \mathrm{O}$ (giving a concentration of $\sim 2 \mathrm{mM}$ ). The cyclization linkers TBMB, TBAB, and TATA were dissolved in $0.5 \mathrm{~mL} \mathrm{MeCN}$ and added to the peptide; 1.1 equivalents were used for cyclization by TBMB and TBAB, and 2 equivalents for cyclization by TATA. The reaction was started by adding $5 \mathrm{~mL}$ of $60 \mathrm{mM} \mathrm{NH}_{4} \mathrm{CO}_{3}, \mathrm{pH} 8.0$. After $1 \mathrm{~h}$ at $30^{\circ} \mathrm{C}$ in a water bath, the reaction was stopped by adding $0.5 \mathrm{~mL}$ formic acid (98\%). The peptides were lyophilized.

Peptide purification by reversed-phase HPLC: Modified peptide powder was resuspended in $1 \mathrm{~mL}$ DMSO, $2 \mathrm{~mL}$ MeCN containing $0.1 \% \mathrm{TFA}$, and $7 \mathrm{~mL} \mathrm{H}_{2} \mathrm{O}$ containing $0.1 \%$ TFA, and purified on a preparative $C_{18}$ column (Vydac $C_{18}$ TP1022 $250 \times 22 \mathrm{~mm}, 10 \mu \mathrm{m}$ ) using a linear gradient of solvent $\mathrm{B}(99.9 \% \mathrm{v} / \mathrm{v} \mathrm{MeCN}$ and $0.1 \% \mathrm{v} / \mathrm{v}$ TFA) over solvent $A\left(99.9 \% \mathrm{v} / \mathrm{v} \mathrm{H} \mathrm{H}_{2} \mathrm{O}, 0.1 \% \mathrm{v} / \mathrm{v}\right.$ TFA) (28 min, 10 $50 \%$, flow rate: $20 \mathrm{~mL} \mathrm{~min}^{-1}$ ). Fractions containing the desired product were identified by ESI-MS analysis and lyophilized.

Fluorescence polarization binding assay: $\beta$-Catenin was serially diluted (twofold, starting from $57.6 \mu \mathrm{m}$ ) in buffer $\mathrm{D}(50 \mathrm{~mm}$ Tris, $\mathrm{pH} 8.8,10 \mathrm{~mm} \mathrm{NaCl}, 10 \% \mathrm{v} / \mathrm{v}$ glycerol, $0.01 \%$ Tween-20); $5 \mu \mathrm{L}$ of each dilution were transferred to wells of a black Corning 384-well flat-bottom polystyrene microtiter plate. $5 \mu \mathrm{L}$ of buffer $\mathrm{D}$ were added to each well, and $5 \mu \mathrm{L}$ of fluorescein-labeled peptide in buffer D (300 nм) were added to each well and incubated for $5 \mathrm{~min}$. Anisotropy of each solution was measured in a multi-well plate reader (Infinite 200 PRO, Tecan) using a $485 \mathrm{~nm}$ excitation filter and a $535 \mathrm{~nm}$ emission filter. For the competition experiments, the same dilutions of $\beta$-catenin were prepared in a 384-well microtiter plate $(5 \mu \mathrm{L}$ per well); $5 \mu \mathrm{L}$ of either $75 \mu \mathrm{m}$ axin $\alpha$-helix (fAx-4-CDCB) or $75 \mu \mathrm{M}$ ICAT (ATGen, Seongnam) in buffer D were added to each well. After $5 \mathrm{~min}$ incubation, $5 \mu \mathrm{L}$ of $300 \mathrm{~nm}$ fluorescein-labeled peptide in buffer $\mathrm{D}$ were added, and anisotropy measured as described above.

\section{Acknowledgements}

Financial contributions from the Marie Curie ITN Sphingonet (PhD fellowship to D.B.) and the Swiss National Science Foundation (Sinergia grant 136245 to J.H., W.H., and C.H.) are gratefully acknowledged. J.H. holds the chair for Signal Transduction in Oncogenesis sponsored by Debiopharm.

Keywords: cyclic peptides - phage display $\cdot$ protein-protein interactions $\cdot$ Wnt signaling $\cdot \beta$-catenin

[1] T. Valenta, G. Hausmann, K. Basler, EMBO J. 2012, 31, 2714-2736.

[2] H. Clevers, R. Nusse, Cell 2012, 149, 1192-1205.

[3] B. T. MacDonald, K. Tamai, X. He, Dev. Cell 2009, 17, 9-26.

[4] W. Q. Xu, D. Kimelman, J. Cell Sci. 2007, 120, 3337-3344.

[5] M. Bienz, H. Clevers, Cell 2000, 103, 311-320.

[6] J. N. Anastas, R. T. Moon, Nat. Rev. Cancer 2013, 13, 11-26.

[7] M. Kahn, Nat. Rev. Drug Discovery 2014, 13, 513-532.

[8] B. M. Gumbiner, Nat. Rev. Mol. Cell Biol. 2005, 6, 622-634.

[9] G. Hahne, T. N. Grossmann, Bioorg. Med. Chem. 2013, 21, 4020-4026.

[10] K. Takada, D. Zhu, G. H. Bird, K. Sukhdeo, J. J. Zhao, M. Mani, M. Lemieux, D. E. Carrasco, J. Ryan, D. Horst, M. Fulciniti, N. C. Munshi, W. Q. Xu, A. L. Kung, R. A. Shivdasani, L. D. Walensky, D. R. Carrasco, Sci. Transl. Med. 2012, 4, 148.

[11] T. N. Grossmann, J. T. H. Yeh, B. R. Bowman, Q. Chu, R. E. Moellering, G. L. Verdine, Proc. Natl. Acad. Sci. USA 2012, 109, $17942-17947$.

[12] C. Heinis, T. Rutherford, S. Freund, G. Winter, Nat. Chem. Biol. 2009, 5, $502-507$.

[13] A. Angelini, L. Cendron, S. Y. Chen, J. Touati, G. Winter, G. Zanotti, C. Heinis, ACS Chem. Biol. 2012, 7, 817-821.

[14] V. Baeriswyl, S. Calzavarini, S. Chen, A. Zorzi, L. Bologna, A. AngelilloScherrer, C. Heinis, ACS Chem. Biol. 2015, 10, $1861-1870$

[15] P. Diderich, C. Heinis, Tetrahedron 2014, 70, 7733-7739.

[16] S. Y. Chen, D. Bertoldo, A. Angelini, F. Pojer, C. Heinis, Angew. Chem. Int. Ed. 2014, 53, 1602-1606; Angew. Chem. 2014, 126, 1628- 1632.

[17] I. R. Rebollo, C. Heinis, Methods 2013, 60, 46-54.

[18] I. R. Rebollo, M. Sabisz, V. Baeriswyl, C. Heinis, Nucleic Acids Res. 2014, 42, 22.

[19] Y. Xing, W. K. Clements, D. Kimelman, W. Q. Xu, Genes Dev. 2003, 17, $2753-2764$.

[20] H. J. Choi, A. H. Huber, W. I. Weis, J. Biol. Chem. 2006, 281, 1027-1038.

Received: November 26, 2015

Published online on $\square \mathbf{\square}, 0000$ 


\section{COMMUNICATIONS}

Hit the target within a target: Bicyclic peptides that bind to different surface regions of $\beta$-catenin were developed by phage display. Several of the ligands compete with the binding of ICAT and therefore bind to the prime target site on $\beta$-catenin for therapeutic intervention.

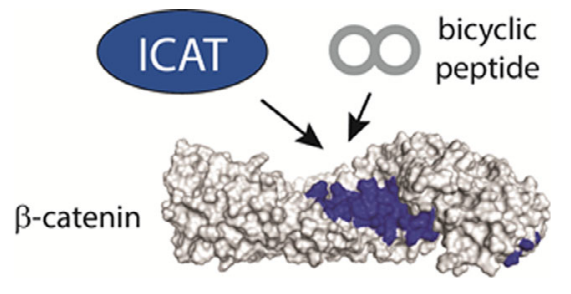

D. Bertoldo, M. M. G. Khan, P. Dessen, W. Held, J. Huelsken, C. Heinis*

Phage Selection of Peptide Macrocycles against $\boldsymbol{\beta}$-Catenin To Interfere with Wnt Signaling 